\title{
Aeronautical English: Investigating the nature of this specific language in search of new heights
}

Inglês aeronáutico: investigando a natureza dessa língua/linguagem em busca de novas altitudes

\section{ABSTRACT}

\author{
Ana Lígia Barbosa de Carvalho e SILVA (UNICAMP) ${ }^{2}$
}

Global communication for professional purposes has opened up new research avenues on English language use in aviation contexts, a growing area of interest in Applied Linguistics. The purpose of this paper is to better understand the nature of the language referred to by the terms aviation English and aeronautical English - and demonstrate how their definitions - and perceptions - can influence the language teaching and assessment for aeronautical communications between pilots and air traffic controllers (ATCOs). To this end, initially, we review the literature to identify what has been researched about the topic. Then, we discuss some problems regarding aeronautical English teaching and assessment that are still unsolved, or have been taken for granted. The expected contribution is to shed some light on what, in fact, should be taught and assessed in this scenario, for better and safer international aeronautical communications.

Keywords: English for Specific Purposes (ESP), Aviation English, Aeronautical English, Language Teaching, Language Assessment.

\section{RESUMO}

A comunicação internacional para fins profissionais tem aberto novas avenidas de pesquisa sobre o uso da língua inglesa em contextos de aviação, uma área de crescente interesse na linguística aplicada. $O$ objetivo deste artigo é fornecer uma melhor compreensão sobre a natureza da linguagem abarcada pelos termos "inglês para aviação" e "inglês aeronáutico", e demonstrar como suas definições - $e$ percepções - podem influenciar o ensino e a avaliação da língua específica para as comunicações aeronáuticas entre pilotos e controladores de tráfego aéreo (ATCOs). Para tanto, inicialmente, revisamos a literatura especializada para identificar o que tem sido pesquisado sobre o tema. Então, discutimos alguns problemas sobre o ensino e a avaliação de inglês aeronáutico que ainda não foram solucionados, ou que têm sido desconsiderados. A contribuição esperada vem no sentido de lançar luzes sobre o que, de fato, deve ser ensinado e avaliado neste cenário, de modo a alcançarmos comunicações aeronáuticas internacionais cada vez melhores e mais seguras.

\footnotetext{
${ }^{1}$ University of São Paulo (USP), São Paulo, SP, Brazil and Airspace Control Institute (ICEA), São José dos Campos, SP, Brazil. Aeronautical English Section, Teaching Department. ORCID: https://orcid.org/0000-0001-9104-2123; patricialucks@gmail.com

2 University of Campinas (Unicamp), Campinas, SP, Brazil. Institute of Language Studies, Department of Applied Linguistics. ORCID: https://orcid.org/0000-0002-0752-2659; analigiasilva7@gmail.com “This study was financed in part by the Coordenação de Aperfeiçoamento de Pessoal de Nivel Superior - Brasil (CAPES) - Finance Code 001".
} 
Palavras-chave: Inglês para Fins Específicos (IFE), Inglês para Aviação, Inglês Aeronáutico, Ensino de Linguas e Avaliação no Contexto de Línguas.

\section{Introduction}

Global communication for professional purposes has opened up new "research airways" on English language use in aviation contexts, a growing area of interest in Applied Linguistics. As for the communication between pilots and air traffic controllers (ATCOs), a lot has been investigated since the publication of the Manual on the Implementation of ICAO Language Proficiency Requirements, (LPRs) ${ }^{3}$ Doc 9835 AN/453 (ICAO, 2010), and two additional documents, the Language Testing Criteria for Global Harmonization, Circular 318 AN/180 (ICAO, 2009a) and the Guidelines for Aviation English Training Programmes, Circular 323 AN/185 (ICAO, 2009b). This paper follows these pathways, learning from previous studies, but aiming at a better understanding of the aeronautical English construct $^{4}$ and its consequences for assessment and teaching.

English is the official language of international aviation and it has become a current practice to refer to different types of communication in such scenario as aviation English. In Doc 9835, ICAO states that "The field covered by the term 'aviation language' is relatively broad. It could include all of the language uses of many different professions (engineers, technicians, commercial staff, flight crews, etc.) within the aviation domain [...]" (ICAO, 2010, item 3.2.6, p. 3-2). Nevertheless, in order to design and develop courses and language proficiency exams that meet the communication needs of pilots and ATCOs, it is crucial to start by investigating the features of the interactions that occur between these professionals, over the radio, during international flights. In fact, understanding what constitutes this specific language, which more recently has been referred to as aeronautical English, is definitely not a "direct flight".

This study aims to demonstrate how the definition of the terms aviation English and aeronautical English can influence the targeting of language teaching and assessment for aeronautical communications between pilots and ATCOs. Based on the assumption that good practices in language assessment can cause positive washback on teaching (CHENG, 2005), we argue that it is not quite feasible to tell apart English for Specific Purposes (ESP) teaching from ESP assessment and, for this reason, teaching and assessment will be jointly considered. Very simply put, language in ESP programs and in ESP assessments should be meaningful and representative of the language used in the real professional world.

\footnotetext{
${ }^{3}$ Note that language testing recommendations are in Chapter 6, and language training guidance is in Chapter 7 of Doc 9835 (ICAO, 2010).

${ }^{4}$ We understand construct as "[...] the theoretical entity that the test developers and the test users intend the test to measure[...]" (DOUGLAS, 2010, p. 33).
} 
We begin by reviewing some problems in the interpretations of the LPRs, which are still unsolved or have been taken for granted. Then, we search for a clear definition of the term aeronautical English, as a subset of aviation English, in order to understand what is the core language to be taught and assessed. This discussion encompasses two concepts reviewed in this study, phraseology and plain language, and how both should be addressed in aeronautical English teaching and assessment. After establishing what is essential in aeronautical communications, we make some comments about other issues that, even not belonging to the realm of aeronautical English, may impact on aviation communications safety. In the concluding section, we summarize the main topics discussed and reinforce our understanding about what we consider fundamental for international pilots and ATCOs' language proficiency. The topics here discussed should be of interest to aviation language program developers, test designers, policy makers, as well as ESP researchers in general. The expected contribution is to shed some light on what, in fact, has to be taught and assessed in this scenario, for better and safer international aeronautical communications.

\section{Looking back to a few unsolved problems}

Initially, we present the mindset that guides aeronautical English teaching and assessment, according to two particular ICAO regulations: i) Doc 9835 (ICAO, 2010) defines aeronautical radiotelephony communications (Chapter 3) and provides guidance on language proficiency teaching and assessment for pilots and ATCOs (Chapter 7; Chapter 6); ii) Circular 323 (ICAO, 2009b) complements it by presenting specific recommendations for course designs, either classroom based or through distance learning, in the same scenario. The Circular enumerates a few characteristics of aeronautical communication as being predominantly oral, with no visual cues, employing a very specific vocabulary to make it clear and unambiguous because it involves risk management not only for pilots and ATCOs but for society at large. It also details the design and development of language courses, including a thorough description of language teachers. These documents reinforce that both teaching and assessment should be guided by ICAO Language Proficiency Rating Scale, Annex 1, Doc 9835 (ICAO, 2010), for speaking and listening proficiency only, according to six differentiating proficiency levels (being 1 the lowest, 6 the highest and 4 the minimum to be considered operational) and band descriptors for pronunciation, structure, vocabulary, fluency, comprehension and interaction.

As it can be observed, pilot-ATCO communication is a rather regulated language, obviously for safety reasons. However, that does not mean that the existing ICAO recommendations are not meant to be questioned and somehow improved. In aviation, as in any other professional area where language risk management is at stake (KNOCH; MACQUEEN, 2020), discussions involving different stakeholders - 
such as language program administrators, test takers and learners, scholars, among others - must be paramount. As Douglas (2014, p. 10) suggests, "We should also work through our professional organizations to encourage ICAO to revise the guidelines for aviation English assessment to adequately reflect the realities of using English as a lingua franca".

With this intent in mind, we discuss some limitations of the rating scale developed by ICAO because of the apparently existing contradictions and multiple interpretations it entails (such as face to face interactions versus voice-only communication), in addition to a number of general English aspects included in the same rating scale (such as the use of idiomatic language). Firstly, Scaramucci (2011) notes that the scale is more likely to have been developed for situations of general use rather than for aviation purposes, and indicates that "indigenous assessment criteria" should be identified for assessment purposes. This means that, apart from pre-established rating scales, it would be appropriate to identify the criteria subject matter experts and experienced professionals often use when judging the communicative performances of their colleagues in the same field (KNOCH, 2014).

Secondly, considering the inconsistencies of ICAO documents about the nature of the language to be taught and assessed, as the ones mentioned above, some language courses and tests based on ICAO recommendations, around the world, tend to focus on aviation English at large, rather than on aeronautical communications. Sometimes the interpretation of Doc 9835 is so broad that the ability to communicate in radiotelephony is mistakenly understood and represented in some test tasks as simply being able to talk about aviation situations. In fact, as pointed out by Garcia (2015), in real life pilots and ATCOs do not have to answer personal questions or express opinions related to aviation to do their jobs, but they do have to interact about situations that happen during the different phases of the flight in radiotelephony communications.

The third point is made by Kim and Elder (2009), Douglas (2014) and Kim (2018), among others, who share the understanding that the oral proficiency construct presented in the holistic descriptors and the ICAO rating scale is too narrow, referring mostly to non-native English speakers, and so they argue in favor of an English as lingua franca (ELF) perspective for what should be measured in tests of aeronautical English. Doc 9835 (ICAO, 2010, item 2.5) claims that radiotelephony communications should follow the ELF framework which is in line with what is argued by many researchers (KIM; ELDER, 2009; DOUGLAS, 2014; ESTIVAL; FARRIS; MOLESWORTH, 2016; PRADO; TOSQUI-LUCKS, 2019). Such perspective comes with key assumptions in regard to crosscultural awareness, the notion of intelligibility far distant from the native-like pronunciation model (JENKINS, 2000), and the expected use of strategic competence, such as accommodation and negotiation of meaning, implicating a shared responsibility for misunderstandings. 
Despite ICAO's efforts in also suggesting the ELF perspective for aeronautical communications, it fails in making it clear in the rating scale. The high levels (5 and 6) do not contemplate the use of communicative strategies, which far from being compensatory should be triggered to facilitate communication (ARAGÃO, 2018). Previous studies have shown that even native speakers of the language need to adhere to aeronautical English standards (GARCIA, 2015; ESTIVAL; FARRIS, 2016). For this reason, we assume that in aeronautical English there is no such thing as "ownership of the language" (WIDDOWSON, 1994), as it is not a register acquired in daily life events (BIESWANGER, 2016). Native and non-native English speakers have to learn it and use it likewise (PRADO; TOSQUILUCKS, 2019) and "[...] no one can really be considered as a native speaker of English radiotelephony" (LOPEZ; CONDAMINES; JOSSELIN-LERAY, 2011, p. 303). Actually, in some cases "[...] in which native speakers had not used the prescribed, formulaic language, but reverted to a more colloquial language, this has played a role in aviation incidents" (BRUNFAUT, 2014, p. 219). More recently, ELF research has highlighted important conceptual developments towards the use of communicative strategies (ISHIHARA; PRADO, forthcoming) and phenomena such as adaptation and accommodation (JENKINS, 2018).

Adding more thoughts to our discussion, we quote Borowska (2017) in her claim that any aeronautical English course should combine the teaching of linguistic and cross-cultural awareness, so that native speakers and non-native speakers can communicate successfully. Similarly, Monteiro (2019) turned her attention to a broader view of what she calls communicative competence for intercultural communications in aviation.

One more aspect studied in recent research, which we consider a fifth unsolved problem, concerns the lack of authenticity in language courses and test tasks related to radiotelephony communications. About this matter, a research area that has been growing is the one that uses corpus linguistics to analyze aeronautical language and provide tools for teachers. Tosqui-Lucks (2018) described 16 studies, from different parts of the world (Europe and North and South America), from the 1990 's to the present date, which analyzed authentic recordings of the language of radio communication, in real air traffic control and/or in simulations and training situations, using the corpus linguistics methodology, with various research objectives, such as language description, language policies for safety, and mainly teaching. The investigations with corpora can equip the researcher and material designer with real language samples and offer the opportunity to bring authentic language to the classroom, supplying the language professional with adequate tools to teach from meaningful input and, as such, promote better output to the students (LOPEZ; CONDAMINES; JOSSELIN-LERAY, 2011; PRADO; TOSQUI-LUCKS, 2017; PRADO; TOSQUI-LUCKS, 2019). Brand new studies are related to 
pragmatics in aeronautical English and how to teach it to pilots and controllers to make them more aware of communication strategies (PRADO, 2019; ISHIHARA; PRADO, forthcoming). Still discussing authenticity, now from a language testing perspective, Knoch and Macqueen (2020, p. 102) argue that "[...] authenticity is not an all or nothing property of test tasks but rather a question of degree" and remind us that authenticity "[...] is multi-faceted, and does not reside only within the test tasks. Test designers need to examine how test tasks are designed, delivered and assessed" (p. 102). While Elder (2015) adds assessment criteria as an important consideration in test authenticity, Douglas (2001) points out that only performance elicited in a way that truly engages test takers with relevant work-related test tasks will make good sources of inferences about the ability to be measured. Accordingly, Knoch and Macqueen (2020) emphasize that needs analysis is a fundamental tool to enhance the correspondence between test specifications, test tasks and assessment criteria.

These are a few of the issues that have been discussed since Doc 9835 publication. It seems that some of the problems mentioned here come from deficiencies in ICAO policy, which also make some stakeholders become reluctant towards it (GARCIA, 2015; KIM, 2013). As mentioned before, our aim is by no means to simply criticize what has been proposed on ICAO documents, but to join the discussion to provide some ideas and try to somehow bring a contribution. In order to do so, we believe it is essential to establish the difference between what is currently understood by aviation English and what we call aeronautical English.

\section{Aviation English or aeronautical English?}

There might be many types of English within the umbrella term aviation English, just as there are numerous Englishes for specific purposes in other fields, considering that different professionals in aviation, such as aircraft maintenance personnel, flight attendants and engineers, to name a few, also use English to communicate in their workplaces. We consider that aviation English is much too broad a term, which could encompass all the language varieties used by many professionals in the field (MODER, 2013), causing ambiguities and misunderstandings. 
Even though the term aviation English is often chosen to refer solely to the language used between pilots and ATCOs in international radiotelephony communications (ICAO, 2010) , we opt for the term aeronautical English to refer to this particular language, because we consider it confusing to have the same term meaning both the hiperonymy and the hiponymy.

As Katsarska (2017) argues, there are many content areas identified in the aviation English scope and "[...] that is why each aviation English course should be developed based on the analysis of the purpose, needs and the specific activities for which language will be needed" (KATSARSKA, 2017, p. 451). Along the same line, some authors (KIM; ELDER, 2009; KIM, 2013) have questioned "[...] what is this thing called aviation English?" (DOUGLAS, 2014, p. 5) that should be measured in tests for pilots and ATCOs.

Our preference for the term aeronautical English, and not aeronautical radiotelephony communications, as presented in Doc 9835 (OACI, 2010, 3.2.7, p. 3-2), is explained by our view that adding the means through which communication between pilots and ATCOs occurs might not be the best alternative. Doc 9835 itself foresees the possibility of data-link applications. In the future, reading and writing might as well be skills to be addressed in aeronautical communications, by other means. We also opted for the inclusion of "English" in the term as a way of recognizing it as the lingua franca in aviation contexts.

It is important to remark that the discussions presented in this study, about these terms and their corresponding meanings, occurred first in Portuguese, the authors' native language, on the creation of a research group called Grupo de Estudos em Inglês Aeronáutico (GEIA) ${ }^{6}$, in 2013. The choice for the term aeronautical English was endorsed by Brazilian aviation authorities, who changed, in 2016, the original name of the exam applied to ATCOs to Exame de Proficiência em Inglês Aeronáutico do Sistema de Controle do Espaço Aéreo Brasileiro (EPLIS) ${ }^{7}$, in a clear intention to make a distinction between this and other language proficiency tests applied in the scope of the Brazilian Air Force, for study and work missions abroad, for example. Since then, all official publications and mentions to the ATCO language proficiency adopted the term aeronautical English.

In the same year, the use of the term aeronautical English was discussed, in Portuguese, in a language needs analysis study developed for a group of military pilots from the Brazilian Air Force Air-

\footnotetext{
${ }^{5}$ ICAO (2010, p. 3-2) "3.2.7 The sole object of ICAO language proficiency requirements is aeronautical radiotelephony communications, a specialized subcategory of aviation language corresponding to a limited portion of the language uses of only two aviation professions - controllers and flight crews. It includes ICAO standardized phraseology and the use of plain language. The standardized words and phrases of ICAO phraseology approved for radiotelephony communications have been developed over the years and represent a true sub-language as defined above. It may be useful to consider aviation language, radiotelephony language, and phraseologies as increasingly smaller subsets within the larger category of "language"”.

${ }^{6}$ In English: Aeronautical English Research Group In: https:/geia.icea.gov.br/geia/inicial.php

${ }^{7}$ In English: Aeronautical English Proficiency Exam of the Brazilian Airspace Control System In: https://eplis.icea.gov.br/
} 
Demonstration-Squadron, Esquadrilha da Fumaça (SILVA, 2016a). The decision to use the term was consolidated with the publication of a book, in Portuguese, with results of GEIA members' research, called Pesquisas sobre Inglês Aeronáutico no Brasil (SCARAMUCCI; TOSQUI-LUCKS; DAMIÃO, 2018) ${ }^{8}$. At the time, the editors decided to publish the volume in Portuguese in order to make information about aviation language broadly available to the Portuguese speakers community. Besides using the term inglês aeronáutico on the title, the book presents a bilingual collaborative glossary, written by all group members, in which a clear distinction between aviation English and aeronautical English is made, while acknowledging that, in English, the term aviation English is sometimes used to refer to both concepts - which can be confusing at times. The objective of the glossary was to establish a harmonization among the group members and, at the same time, serve as recommendations or suggestions to other users. Table (1) below, adapted from this glossary, presents the terms in English, as well as their translations to Portuguese and their meanings in English:

Table 1. Definitions of aviation English.

\begin{tabular}{|l|l|l|}
\hline English & Portuguese & Definition/Conceptualization \\
\hline aviation English (1) & inglês aeronáutico & $\begin{array}{l}\text { Denomination given to the language used in communications that take } \\
\text { place during a flight in an international environment, between pilots and } \\
\text { air traffic controllers. It comprises standard phraseology and plain } \\
\text { English. }\end{array}$ \\
\hline aviation English (2) & $\begin{array}{l}\text { inglês para } \\
\text { aviação }\end{array}$ & $\begin{array}{l}\text { One of the possible translations, into Portuguese, of the term aviation } \\
\text { English, taken in its broadest meaning. It comprises both aeronautical } \\
\text { English and other uses of English in the communication between multiple } \\
\text { aviation professionals, such as pilots, crew members, aircraft mechanics, } \\
\text { among others. }\end{array}$ \\
\hline
\end{tabular}

Source: translated from Scaramucci; Tosqui-Lucks; Damião (2018, p. 296-297).

Since then, we have advanced on the reflections about these terms on other studies. TosquiLucks and Silva (2020) considered that:

[...] although a concept can usually be defined by more than one term, since synonymy indicates the richness of language, the results [of this study] evidence that, in the field of aviation, a single term should not have more than one interpretation for a specific use, both for theoretical and methodological issues in the disciplinary field of Terminology and for the risk of threat to air safety (TOSQUI-LUCKS; SILVA, 2020, p. 112) .

Hence, once the difference in meaning of inglês aeronáutico and inglês para aviação in Portuguese was clear to us, the transposition of this terminological choice to the English language was simply a natural process. As Solovova, Santos and Verissimo (2018) state:

\footnotetext{
${ }^{8}$ In English: Research on Aeronautical English in Brazil.

${ }^{9}$ Original: “[...] embora um conceito normalmente possa ser definido por mais de um termo, pois a sinonímia sinaliza a riqueza da linguagem, os resultados [deste estudo] evidenciam que, na área de aviação, um único termo não deve ter mais de uma interpretação para determinado uso específico, tanto por questões teóricas e metodológicas do campo disciplinar da Terminologia quanto pelo risco de ameaça à segurança aérea".
} 
[...] English is nowadays considered the language of science. Its lingua franca status has had a substantial impact on the construction, dissemination and communication of scientific knowledge, on the statuses of other languages in which scientific knowledge is being produced and disseminated, and ultimately on the opportunities they bring to researchers around the world. Articles and other scientific texts written in English are accessible to larger research communities [...], since publishing in a language other than English means restricting knowledge dissemination to highly specialized and closely-knit research communities (SOLOVOVA; SANTOS; VERISSIMO, 2018, p. $01)$.

Although we are aware that changes take time, and that many authors have been using aviation English meaning its restricted scope that we consider aeronautical English, probably influenced by ICAO documents, we insist that the use of different terms to refer to two different concepts, especially when one encompasses the other, has important consequences, as we attempt to show in this paper. In fact, we have found an echo among the international community as Borowska (2017) made the claim that:

The name Aviation English suggested by ICAO may be misleading and confusing at times. It analogically imposes its meaning to all other aviation languages so that they end up being named in a similar way, e.g. Aviation Spanish, Aviation Polish, etc. It also deprives us of any other possibility of referring to the superior construct to all the sublanguages of aviation domain because one term cannot mean here two constructs (BOROWSKA, 2017, p. 64).

In line with this reasoning, the same author explains:

I wish to make a clear distinction between Aviation English and Aeronautical English, and not to use them interchangeably. Therefore, to narrow the reference down I will use the term Aeronautical English (AeE) for radiotelephony English which covers both Standard Phraseology (SP) and Plain Aeronautical English (PAE). (BOROWSKA, 2017, p. 67).

Now we turn to what ICAO documents have published about this matter. In 2004, after a few fatal accidents which had communication problems as one of their contributing factors, ICAO issued Doc 9835 to put together English language proficiency requirements for international pilots and ATCOs. This document, reviewed in 2010, sustains that pilots and ATCOs should be able to communicate, in routine situations, through a highly specific code for aviation purposes, i.e. aeronautical standard phraseology $y^{10}$, and plain language whenever phraseology does not suffice to communicate in non-routine situations. As for the concepts of standard phraseology and plain language, they are not consensual either, and authors use different terms such as "plain Aviation English" (BIESWANGER, 2016, p. 80) and "Plain Aeronautical English" (PAE) (BOROWSKA, 2017, p. 90) in an attempt to elucidate them.

\footnotetext{
${ }^{10}$ ICAO recommendations for the use of standard phraseology can be found in Doc 9432, Manual of Radiotelephony (ICAO, 2007) and Doc 4444, Air traffic management (ICAO, 2016).
} 
Precisely because it constitutes one of the elements of radiotelephony communications, the socalled plain English must be used according to the same rules of conciseness, precision, objectivity, intelligibility and unambiguity that govern the use of phraseology (ICAO, 2010, p. 3-5, item 3.3.14). For this reason, it can only be associated with plain English as opposed to the term phraseology, in no way having the connotation of English for use in common everyday situations (SCARAMUCCI, 2011; BOROWSKA, 2017), nor for use in the other aviation contexts, which escape communication by radiotelephony. Therefore, it is good to reinforce, it does not constitute plain English, for example, interactions between aircraft engineers and mechanics, on the ground, nor between flight attendants, during a flight, or even between pilots, on the ground, in a situation other than a flight (TOSQUILUCKS; SILVA, 2020, p. 109). We will return to this discussion, but first we wish to analyze visual representations of the concept of aeronautical English as a subset of aviation English.

In the same year of publication of the first version of Doc 9835, Mathews (2004) presented a graphic of sets and subsets to represent the structure of aviation language (Figure 1).

Figure 1. The structure of aviation language.

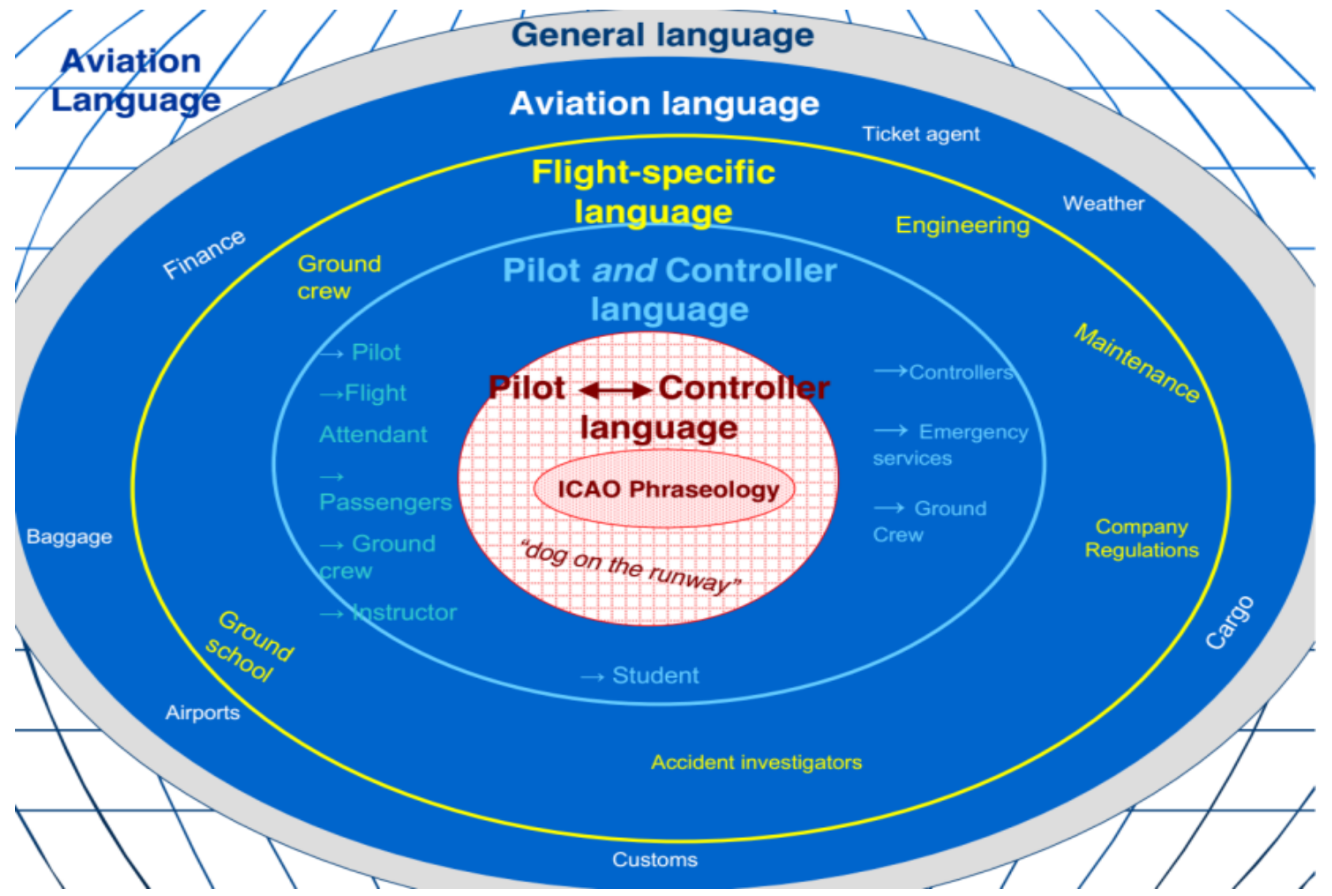

Source: Mathews (2004). 
The inner circles, in red, represent the scope of aeronautical English, that is, communication restricted to pilots and controllers during the phases of a flight, comprising phraseology (for example, giving clearance for landing or taking off) and plain language (for example, when it is necessary to inform that there is an animal, like a dog, on the runway). This portion of the figure represents the core of pilot-ATCO communication. As the circles expand, they start to involve communications during a flight that may occur between other aviation professionals: those who talk to pilots (such as flight attendants, passengers, among others) and to ATCOs (such as other ATCOs, emergency services, ground crew, among others) and other contexts that precede or succeed the flight (such as maintenance or accident investigation). The outer layers of the circle include other professionals or areas that are broadly related to aviation, such as ticket agent and customs agents, having no direct relation with pilotcontroller communication during a flight.

For many years, researchers of the area have devoted efforts to defining radiotelephony communication contexts by digging into the meaning of both phraseology and plain language. Despite the number of ICAO publications to establish and maintain the LPRs for pilots and ATCOs, along with the efforts of international forums to discuss them and the growing number of academic researches about the matter ${ }^{11}$, many authors (ALDERSON, 2008; MODER; HALLECK, 2009; EMERY, 2014; GARCIA, 2015; ARAGÃO, 2018) have been arguing that the interpretations of LPRs' standards over the years are far from harmonized. For this reason, the International Civil Aviation English Association (ICAEA), with the support of ICAO, in 2019, promoted four workshops ${ }^{12}$ in different parts of the world, in order to try to standardize divergent interpretations of Doc 9835 regarding test instrument design features. The idea was to guide stakeholders, such as test designers, test takers and test score users to reach a common ground on what a language proficiency test for pilots and ATCOs should really encompass. Figure 2, taken from ICAEA Test Design Guidelines (TDG) workshop presentations (ICAEA, 2019a, session 2, slide 7), visually demonstrates the domain of what we name aeronautical English.

\footnotetext{
${ }^{11}$ See Aviation English Hub for a constantly updated list of references: https://aviationenglishhub.wordpress.com/

${ }_{12}$ Luxembourg, 9-11 October 2019; Tbilisi, 14-16 October 2019; Bankok, 28-30 October 2019; Buenos Aires 20-22 November 2019. One of the authors of this study participated in this last event, which mainly, but not exclusively, targeted Latin American participants.
} 
Figure 2. The domain of aviation language.

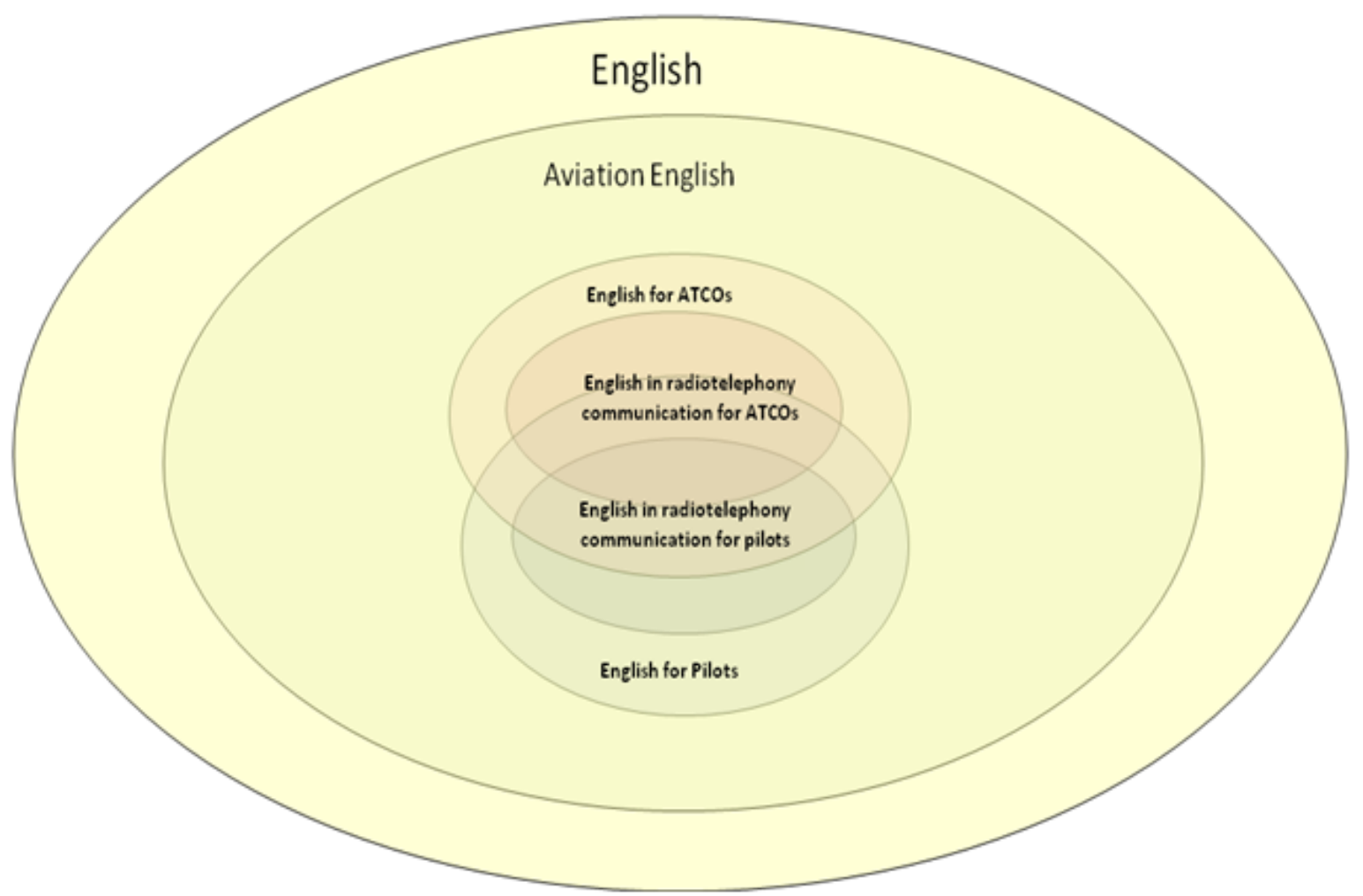

Source: TDG workshop presentation (ICAEA, 2019a, session 2, slide 7).

Despite being separated by 15 years, Figure 1 and Figure 2 contain many similarities. Both acknowledge that the term aviation English is very broad and comprehend an area of ESP, but that the "portion" that matters for ICAO safety purposes is the radiotelephony communication between pilots and ATCOs, represented in the inner circles. However, it is important to notice that Figure 2 presents other layers and intersections in pilots' and ATCOs' communications. According to the new ICAEA TDG, the core language to be assessed in language proficiency tests for pilots and ATCOs - and, expectedly, to be taught and practiced in language programs - "[...] should mirror the kind of communication settings and contexts associated with real-world situations that pilots and air traffic controllers may face, both in radiotelephony communication contexts and other job-related communication contexts" (ICAEA, 2019b, p. 12). Roberts and Orr (2020, p. 150) follow the same idea, stating that "[...] a concise and comprehensive definition of the construct of aviation English is difficult to provide given the numerous contexts in which it is used".

In defining aviation and aeronautical English, it seems that, now, we ought to go further and investigate what is meant by "other related contexts", as cited above. We believe these contexts could be interpreted as the communications directed towards other professionals during the flight, such as: i) 
for pilots: flight crew, flight attendants, passengers, instructors, among others; ii) for ATCOs: other ATCOs, emergercy services, ground crew, among others, exactly like exemplified in Figure 1. According to our definitions, presented in Table 1, these other contexts would not be part of the aeronautical English definition, but of aviation English. They belong to the layers of pilot communication and of ATCO communication that are associated with the definition of aviation English as represented in Figure 2. Even though these communications are not radiotelephony and do not belong to the scope of aeronautical English, they may, in different degrees, have a role in safety, as we will discuss in Section 6.

\section{Elements of aeronautical English}

Aeronautical communication is guided by regulations and recommendations and involves the use of listening and speaking skills ${ }^{13}$, over the radio, in two sublanguages, or registers (BIESWANGER, 2016) for aviation settings, i. e. standard phraseology and plain English. It also demands a tricky transition between both during use.

In real life, both ATCOs and pilots have to use language to make crucial decisions and to take action, in each case, either to control international air traffic or to fly and navigate, which requires a lot of attention, focus and, to some extent, memory ${ }^{14}$. Meanwhile, these professionals may need to talk to their peers, in English or in another language, which may or may not occur in their native language, adding more stress components to the interaction, in a phenomenon called code-switching ${ }^{15}$. PilotATCO communication also encompasses language precision for risk management reasons, integration of language and background knowledge, no face to face interaction, interlocutors with different language accents, participants from different cultural backgrounds, among other idiosyncracies that make this specific language so difficult to be pinned down for teaching or assessing purposes. These elements are expressed by means of phraseology and plain language, core elements of aeronautical English, whose nature we discuss as follows.

\footnotetext{
${ }^{13}$ We are not considering the use of datalink communication because it hasn't been applied to all air traffic control (ATC) contexts yet.

${ }^{14}$ A preliminary investigation at Brazilian ATC facilities - area control center (ACC), approach control (APP) and tower (TWR) - revealed that memory is not an essential cognitive ability for construct defining purposes. More research about it related to pilots and controllers would be desirable.

${ }^{15}$ Even though ICAO refers to "[...] the effective transition between standard phraseology and plain language" as "codeswitching'(ICAO, 2010, section 3.3.21) too, here we mean the transition between two different languages, for example English and Portuguese, involving the use of standard phraseology and plain language in both languages, during the same flight or work shift.
} 


\subsection{The nature of phraseology and plain language}

In search for a definition of the terms phraseology and plain language, in the aviation context, again we turn to the glossary published by Scaramucci, Tosqui-Lucks and Damião (2018):

Table 2. Definitions of phraseology and plain English.

\begin{tabular}{|l|l|l|}
\hline English & Portuguese & Definition/Conceptualization \\
\hline $\begin{array}{l}\text { phraseology } \\
\text { (standard } \\
\text { phraseology) }\end{array}$ & $\begin{array}{l}\text { fraseologia (fraseologia } \\
\text { aérea padrão por } \\
\text { radiotelefonia); fraseologia } \\
\text { padrão; Fraseologia } \\
\text { Aeronáutica }\end{array}$ & $\begin{array}{l}\text { It is a code used by pilots and air traffic controllers, restrictly and predictably } \\
\text { used in a limited number of communicative events characterized by short } \\
\text { phrases and reduced vocabulary which allows a concise, precise and efficient } \\
\text { transmission of information related to a flight. }\end{array}$ \\
\hline $\begin{array}{l}\text { plain } \\
\text { plainglish, } \\
\text { language }\end{array}$ & $\begin{array}{l}\text { inglês comum, língua } \\
\text { comum para comunicação } \\
\text { aeronáutica }\end{array}$ & $\begin{array}{l}\text { It is the use of the (English language) in radiotelephony communication that } \\
\text { exceeds the use of standard Phraseology, when it is not sufficient, but that } \\
\text { should mirror phraseology, keeping its characteristics and specificities, as well } \\
\text { as the same critical safety requirements such as intelligibility, non-ambiguity } \\
\text { and concision. }\end{array}$ \\
\hline
\end{tabular}

Source: translated from Scaramucci; Tosqui-Lucks; Damião (2018, p. 300).

Doc 9835 (ICAO, 2010), when describing aeronautical radiotelephony communications, in Chapter 3, item 3.2.7 includes phraseologies in the category of "[...] smaller subsets within the larger category of "language"” (ICAO, 2010, p. 3-2). Likewise, item 3.3.9 maintains that phraseology is "[...] a kind of jargon, a specialized code" (ICAO, 2010, p. 3-4). From reading the document up to that point, it seems reasonable to infer that phraseology belongs to the realm of language, and as such it should be taught and assessed. However, things are not that simple. Leaving room for divergent interpretations, Doc 9835 - Chapter 6, entitled Language Testing Criteria for Global Harmonization - item 6.2.8.4 defines phraseology as a "[...] formulaic code made up of specific words that in the context of aviation operations have a precise and singular operational significance" (ICAO, 2010 p. 6-6), and in item 6.2.8.6, on the same page, it maintains that "Teaching and testing standardized phraseology are operational issues, not a language proficiency issue". In short, as far as the nature of phraseology is concerned, different stakeholders, referring to Doc 9835, could find argumentation for opposite points of view. According to the same document:

Plain language in aeronautical radiotelephony communications means the spontaneous, creative and non-coded use of a given natural language, although constrained by the functions and topics (aviation and non-aviation) that are required by aeronautical radiotelephony communications, as well as by specific safety-critical requirements for intelligibility, directness, appropriacy, non-ambiguity and concision (ICAO, 2010, 3.3.14, p. 3-4).

As we stated in the beginning of the text, good practices in language assessment can cause a positive washback effect on teaching. Unfortunately, the opposite is also true. The notion of plain language offered by Doc 9835 is not always clearly understood by professionals in charge of 
aeronautical English teaching. It is difficult to determine how "[...] spontaneous, creative and noncoded language can reflect the features of clarity, concision and preciseness that must characterize radiotelephony communications" (LOPEZ; CONDAMINES; JOSSELIN-LERAY, 2011, p. 303).

Bieswanger (2016, p. 83) cites Biber and Conrad (2009, p. 45) in saying that, in ATC communication, "[...] routine and non-routine situations alternate constantly, meaning that changes in communicative purpose and switching from standard phraseology to plain aeronautical English are the rule rather than the exception. As Prado and Tosqui-Lucks (2019) argue, standard phraseology and plain English are so interconnected that it is difficult to establish at which point the former ends and the latter begins.

At this point, we would like to reinforce what seems to be an issue that has been taken for granted and which directly impacts aeronautical English teaching and assessment. We ask: given its encoded and technical characteristics, should phraseology be considered content knowledge, language or something in between? The way we see it, it comprises both content and language. Consequently, phraseology should not continue to be taught and assessed totally separately, as it is now suggested by ICAO, but somehow more integrated with plain English. In our view, phraseology in English should be addressed in the syllabus of aeronautical English courses, at least to some extent, and in test tasks designed to assess pilots and ATCOs' language proficiency. In order to accomplish it, the questions that still must be answered are: How? To which extent? Who would the teachers, and the raters be: language or occupational specialists? We believe the solution is to take advantage of the combination of language experts and subject matter experts. Meanwhile, further research is needed so as to find the most appropriate way of teaching and assessing standard phraseology, in English, for non-native pilots and ATCOs, who presumably have previously learned it in their own language. As for native English speakers, we believe that standard phraseology and its transition to plain English should also be jointly taught and assessed, considering ELF communicative strategies, such as adaptation and accommodation to an international community of speakers, cross-cultural awareness, respect to phraseology and its principles (clear, concise, precise language) and other aspects mentioned before.

\section{ESP issues related to aeronautical English learning and assessment}

We now turn to what constitutes the first step on the development of any language course or language test design, especially those for professional purposes, and that is: needs analysis (HUTCHINSON; WATERS, 1987; ROBINSON, 1991; DUDLEY-EVANS; ST. JOHN, 1998). Even though most work on needs analysis can be found in the area of language curriculum design (FLOWERDEW, 2013), it is also crucial to language assessment design. It is our belief that only with a 
clear understanding of the nature of the language needed in the target language situation, through a comprehensive needs analysis, can we get to the concept of language proficiency to be taught or assessed in professional contexts (SILVA, 2016a; 2016b; SILVA, 2018; SILVA, 2019). In short, the results of a language needs analysis can build the rationales for the development of effective language programs, including syllabus and material design, and they can provide substantial information for language test design too.

When enumerating the characteristics of ESP, Douglas (2013, p. 368) argues that: i) language varies with context; ii) language is precise; iii) there is interaction between specific purpose language and background knowledge. Therefore, teaching and assessing languages for specific purposes (DOUGLAS, 2000), or English for professional purposes (KNOCH; MACQUEEN, 2020), has its own particularities. Douglas $(2010$, p. 20) also reminds us, "[...] that language is never used in a vacuum, that we don't simply speak, write, read or listen. We always do so for a purpose, related to the context, the situation we are in".

The first point made by Douglas (2013) regards the level of language specificity in diverse workrelated situations. For obvious practical reasons, it is not feasible to develop a language course, or to design a test, which fulfills every singularity of a given professional context. Nevertheless, the differences encountered in the Target Language Use (TLU) domain should always be taken into account. That seems to be a never-ending dilemma faced by all ESP professionals. In the aviation field, it is not different. Language used by pilots on international flights differs significantly from that used by flight attendants, a helicopter pilot uses language similarly to, but not exactly in the same way as a jet pilot, and pilots in general use language differently when communicating with an ATCO over the radio or with an aircraft mechanic on the ground.

The second feature of ESP, highlighted by Douglas (2013), is language precision, which should be sought to mitigate the possibility for ambiguity and misinterpretation. As we maintain in this study, we shall be precise in the very name chosen for the type of language used by pilots and ATCOs on radiotelephony communications: aeronautical English.. In the case of aeronautical English, precision is justified as a way of enhancing risk management, ensuring efficient radiotelephony communications. Corroborating this idea, Doc 9835 states that “[...] inaccuracy and misunderstandings in aviation radiotelephony communications represent a danger to human lives" (ICAO, 2010, item 3.3.4) and for this reason radiotelephony communications must be intelligible, direct, appropriate, non-ambiguous, concise and clear (ICAO, 2010, items 3.3.14; 3.3.20). In other words, it must be precise.

Finally, another key feature of ESP, which language researchers have long grappled with, is the inextricable relationship between language ability and background knowledge (DOUGLAS, 2000, 2013, 
2014), or professional knowledge (KNOCH; MACQUEEN, 2020). Learners and test takers in ESP are skilled professionals who possess subject or professional knowledge and expertise that is brought into the language learning and assessment scenarios, and that is exactly what makes language specific, after all.

As for language assessments, Knoch and Macqueen (2020, p. 104) argue that "[...] despite the fact that all language assessments are designed to assess language, it is difficult and also not desirable to do this free of content". Even though background knowledge was once thought to cause construct irrelevant variance, now we see that researchers and test developers are re-thinking this point of view. In practice, how to design, develop and administer a language course and a language test that combines background knowledge and language knowledge is still a complex matter for applied linguists, which should continue being investigated (LLOSA, forthcoming). If that becomes the mainstream understanding from now on, it is highly recommended that ICAO make it clear on its regulations, so that the same stated construct would be operationalized in different test instruments and a similar syllabus would be followed in language programs around the world, achieving the expected harmonization that could lead to safer flights. Otherwise, we would continue facing some unsolved problems, such as validation issues regarding different test instruments assessing different aspects of language, that is, different constructs, for the same purpose.

Bearing in mind the features of ESP teaching and assessment, we would like to discuss what we consider central to the building of a syllabus for any aeronautical English teaching program, and to the definition of a test construct for aeronautical English assessment. Based on what the most recent studies have to say about English assessment for professional purposes (KNOCH; MACQUEEN, 2020), we hope to bring some contribution to the development of aeronautical English teaching programs as well.

From the very beginning of any language test design, we have to define the underlying ability, or trait, that will be measured by the test. That means questioning our theoretical perspectives and stances on what assessment and language mean. As Scaramucci (2011, p. 9) puts it, "Many exams assess only language knowledge and not necessarily language use. Defining what the test construct will be like depends on our understanding of what will be assessed"16. In recent studies related to language assessment for professional purposes, Knoch and Macqueen (2020, p. 40) conceptually define the term construct as "[...] a language proficiency, skill or ability that is assumed to underlie communication in an actual, specific world of work". These authors propose a detailed characterization of test content and its relation to language use in ESP assessments. They suggest that the construct of a test for professional

\footnotetext{
${ }^{16}$ Originally: "Muitos exames avaliam apenas conhecimentos sobre a língua e não necessariamente uso da língua. Definir qual vai ser o construto do exame depende de como entendemos aquilo que iremos avaliar".
} 
purposes should be determined by a sampling from what they term "Codes of Relevance", as shown in Figure 3.

Figure 3. Codes of Relevance (CoR model) for sampling behaviors in language tests for professional purposes.

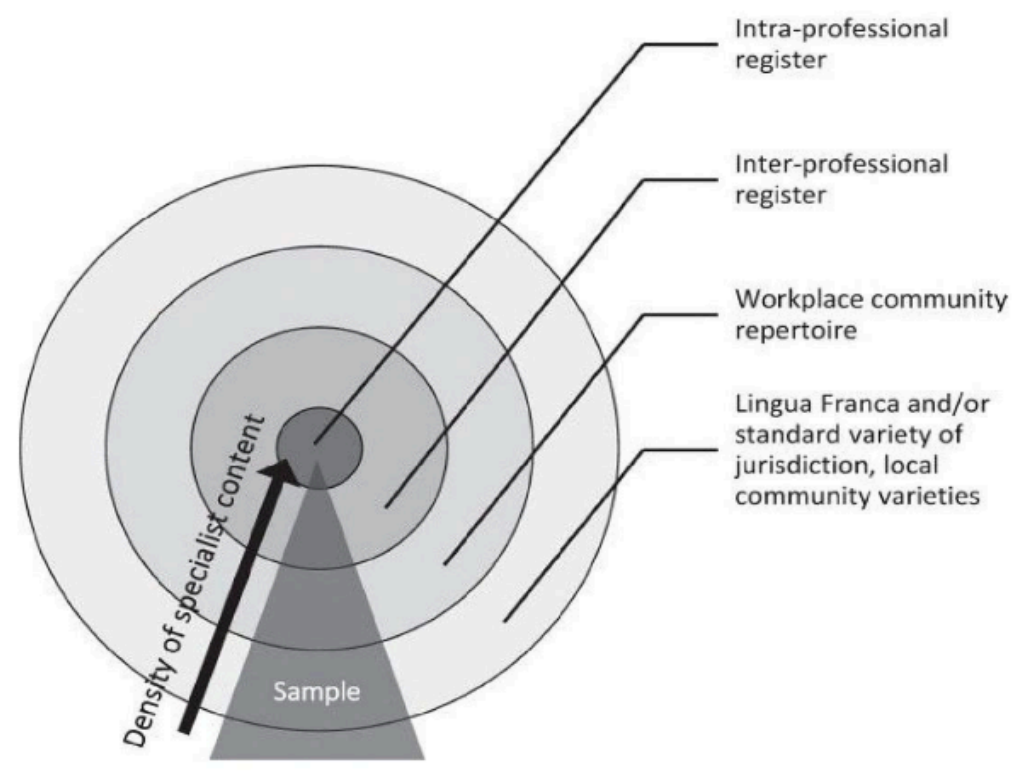

Source: Knoch; Macqueen (2020, p. 61).

These codes correspond to a series of language-using behavior, distributed in a diagram with the innermost circles representing the codes with more specialist knowledge, and, therefore, with more language-content inseparability (KNOCH; MACQUEEN, 2020). In an attempt to adapt this model to the aviation context, and identify pilots' and ATCOs' English language needs for professional purposes, we consider that the innermost circle, containing intra-professional register, represents the language used between these pilots and ATCOs during radiotelephony communications, where the essence of pilotATCO communication is concentrated. Therefore, that is the language that has to be represented in different tasks in aeronautical English test instruments, and that should be included in syllabuses of aeronautical English courses. As Knoch and Macqueen (2020, p. 62) explain, “[...] here you would find specialist content which cannot be readily 'translated' into a code understandable to laypeople without a great deal of interpretation and loss of precision". The next layer, the "inter professional register circle", presents the communications between those who share some professional knowledge in their areas of work. To illustrate, we could mention communications between pilot and copilot in the cockpit, or between pilots and flight engineers, or pilots and other crew members. Another example would be the conversation between controllers from different air traffic control (ATC) facilities who need to 
communicate in English. The following circle is the "workplace community repertoire", which represents a combination of "community varieties and professional register" (KNOCH; MACQUEEN, 2020, p. 63), having laypeople and professionals as participants in communications. In aviation contexts that could be, for example, communications between a pilot and passengers, to welcome them aboard and give them flight information in a simple way, avoiding technical language. As we can observe, this type of language is not directly related to flight safety. The outermost circle represents "the varieties used in the broader social context of the TLU domain" (KNOCH; MACQUEEN, 2020, p. 62). In terms of the language needed by pilots and ATCOs, that would be the least operational sort of work-related language, in situations such as ground communication in informal meetings and everyday interactions in the workplace. As we tried to demonstrate, the nature of the aviation language to be taught and assessed - according to pilots and ATCOs' needs - is very specific and, yet, complex. Thus, we have to make sure that it is effectively identified and represented, in order to generate good samples of what pilots and ATCOs will find in the TLU situation ${ }^{17}$.

In the intra-professional register circle illustrated in the figure above, it is still important to notice that even though ICAO language proficiency scale is the same for pilots and ATCOs, pilots and ATCOs perform different tasks during a flight. Likewise, we keep questioning the essence of pilot-ATCO communication by wondering what these interactions have in common, assuming that they divert at some point, since the situations in which a pilot uses aeronautical English is not exactly the same as an ATCO's situation. As Emery (2014, p. 203) puts it, “[...] flying aircraft and controlling traffic are very different roles, and within the parameters of aircraft performance, operating procedures, airspace, and aerodrome organization and infrastructure, the pilot and air traffic controller officer pursue different objectives". Not only that, but considering the multiple layers in Figure 3, it seems that pilots face more situations than ATCOs, in which they need to talk to other professionals at the same time they are communicating with ATCOs via radiotelephony, as we have discussed in Figure 1, regarding flight attendants and passengers, for example.

\section{Other needs and contexts}

Returning to the idea presented on section 2, we agree that aeronautical English is the main type of communication needed by pilots and ATCOs. However, researchers in the area - in very recent studies - are stretching the perspective of what may constitute professional communication for pilots and ATCOs in international civil aviation. That is exactly when language needs analysis comes to the

\footnotetext{
${ }^{17}$ We acknowledge that reading and writing can be part of the aviation language needs (such as in for reading manuals or writing reports), but those skills are beyond the scope of this article.
} 
fore, in a dynamic and iterative process of reviewing and re-evaluating professionals' language needs (SILVA, 2016a). Consequently, what has to be included in a language course syllabus, and what should be part of tasks in a proficiency exam for pilots and ATCOs will have to be reviewed. For example, Mathews (2020) argues that "[...] not every language-related accident involves air traffic control. Threat and error management require clear communication between all members of a flight crew." The author adds that:

Global aviation is still struggling to comply with the ICAO language standards, which address only speaking and listening proficiency requirements for pilot and air traffic control radiotelephony communications. The standards do not address the more intensive oral communications required for multilingual flight deck communications or for flight training in English. There are no ICAO language standards for maintenance technicians, and there are no ICAO reading proficiency requirements for pilots, controllers or maintenance technicians (MATHEWS, 2020, online).

Roberts and Orr (2020) refer to Circular 323 (ICAO, 2009) to explain that:

[...] when considering a skill such as speaking, a pilot must have the specific ability to comprehend and produce technical aircraft-related utterances during communications with the air traffic control, but also have the broader ability to participate in recurrent training, interact with the crew onboard, report information to maintenance personnel, and so on (ICAO, 2009) (ROBERTS; ORR, 2020, p. 151).

In short, the concept of aeronautical English, although essential for pilot-ATCO communications, might not be sufficient for all contexts of language use these professionals find at work. We have to look beyond aeronautical English and observe other language uses by pilots and by ATCOs, while interacting with other crew members or with other ATCOs, in operational tasks during international flights, to perceive what, or if, other elements should be included in the real scope of the language needed by these professionals. At least, this is what we can infer from recent studies, and from the inclusion of "other related contexts" in these professionals' real-world communication needs, according to recent guidance from ICAEA TDGs (ICAEA, 2019b).

At this point, we would like to return to another idea presented in the beginning of this text. Globalization has brought new job opportunities without borders and global communication for professional purposes has proved to be a necessity. Now, we invite the reader to imagine a crew constituted by a Brazilian captain, a Chinese first officer and a Turkish second officer, working for an Emirate airline and flying to Europe. The interactions among these professionals inside the cockpit will necessarily occur in English, as well as the communication with ATC facilities from different countries, and possibly none of them will be speaking their native languages. Another exercise for our imagination regards ATCOs working in international environments. This may not be the case in Brazil, where, today, domestic flights are in the majority and Portuguese is the language used by all the professionals 
inside Brazilian Air Traffic Control (ATC) facilities - the code switch occurs exclusively when a pilot contacts the ATC facility in English. However, it could be the case of a controller from an approach control facility in Belgium coordinating with an area control center in the Netherlands, or a Croatian trainee ATCO having practical lessons in Germany ${ }^{18}$. As world aviation grows, these situations are likely to become more and more common. Are they under the scope of aeronautical English or aviation English?

Considering our definition in Table 1, they could not be considered aeronautical English, for they are not pilot-ATCO communications. How can they be classified, then? We appeal again to Figures 2 and 3 to state that they would belong to the realm of aviation English. Even not being part of aeronautical English, these communications - which occur in English inside the cockpit and at the ATC facilities, including technical and operational aspects of the flights - are undoubtedly crucial for safety. Should they be taught or assessed? The answer is: it depends on the aim of the language course or on the purpose of the language test. Not all of the situations mentioned above correspond to the "real world" of all pilots and controllers. Private pilots, who fly single, do not talk to copilots, flight attendants or passengers, for example. Countries where ATCOs communicate to each other in the local language, for instance, do not use English for these purposes. Therefore, we understand that aeronautical English for them should be enough.

\section{Final considerations}

As we have seen, despite the many studies devoted to the matter, the understanding of the concepts underlying aviation English and aeronautical English, still seems to be blurred, as they overlap to some point, with consequences for the teaching and assessment of the language needed by pilots and ATCOs. In the international community, there are those who either teach or assess a more general English, not taking radiotelephony communications into consideration, while others concentrate their practices on a too narrow scope, based on technical/operational language, not giving enough attention to the broad array of situations and language interactions that may arise during an international flight.

In this article, we attempted to establish a distinction between the term aeronautical English and other contexts of language use entailed by the umbrella term aviation English. This is not for the sake of Terminology only, but to ensure that the concept is clearly defined and shared by the professionals in charge of teaching and assessing pilots and ATCOs. Today, the lack of precision of Doc 9835, added to

\footnotetext{
${ }^{18}$ These hypothetical examples were based on information collected with pilots, ATCOs and language teachers from these countries during the workshops of the ICAEA Forum in Dubrovnik, Croatia, in 2017. Information about a joint initiative for the unification of European airspace can be found at: $<$ https://www.crocontrol.hr/default.aspx?id=228>.
} 
the fact that ICAO rating scale is somehow based on an English for general purposes perspective, tend to cause different interpretations and misunderstandings.

By presenting teaching and assessment recent research, we reinforce that needs analysis is fundamental for a better understanding of pilots and ATCOs' different and mutual characteristics and learning needs. Corpus linguistics seems to bring some light into aeronautical English by making possible the analysis of real samples of these professionals' communication, contrasting efficient and inefficient language exchanges, in a lingua franca community with shared responsabilities and no native speakers. Current findings in assessment research also highlight the importance of new models of construct definition, integration between language and background knowledge, and a broad understanding of what authenticity entails.

In our view, there is still the need for further research on the nature of phraseology to decide how to address it in language courses and to what extent it has to be assessed and how. Not only that, but it is also necessary to have a clear definition of the extent to which the teaching and assessment of language for pilots and ATCOs should go beyond radiotelephony communications. For this reason, we suggest a revision of ICAO LPRs for a more transparent definition of the construct of aeronautical and aviation English that could be better understood by the international community.

To conclude, we recognize our shared responsibilities in providing evidence-based test scores to support stakeholders to make fair and just decisions, as well as in designing meaningful and effective language programs for pilots and ATCOs. In this matter, we reassure the importance of research groups dedicated to aeronautical English, like GEIA in Brazil and ICAEA, as forums for sharing research results and promoting opportunities for on-site and virtual interactions and experience exchanges. It is our belief that only by designing and implementing ESP tests and courses which meet pilots and ATCOs' real language needs will we all have better aeronautical communications and safer skies.

\section{Acknowledgements}

We would like to thank Profs. Dan Douglas, Malila Carvalho de Almeida Prado and Beatriz Faria Aragão for their valuable contributions to earlier versions of this paper, and the two anonymous reviewers for their insightful comments. 


\section{References}

ALDERSON, J.C. 2008. Final Report on a Survey of Aviation English Tests, 2008. Available at:< http://www.ealta.eu.org/documents/archive/alderson_2008>. Access: 23 Mar. 2020.

ARAGÃO. B. F. 2018. O uso de critérios autóctones no contexto aeronáutico: contribuições para uma nova escala de proficiência em inglês aeronáutico. In: SCARAMUCCI, M. V. R.; P. TOSQUI-LUCKS; S. M. DAMIÃO (Eds.). Pesquisas sobre inglês aeronáutico no Brasil. Campinas: Pontes. p. 243-270. BIBER, D.; S. CONRAD. 2009. Register, genre, and style. Cambridge: Cambridge University Press. $339 \mathrm{p}$.

BIESWANGER, M. 2016. Aviation English: Two distinct specialised registers? In: SCHUBERT, C.; C. S. STOCKHAMMER (Eds.). Variational Text Linguistics: Revisting Register in English.

Berlin/Boston: De Gruyter Mouton. p. 67-86. e-book

BOROWSKA, A.P. 2017. Avialinguistics: The Study of Language for Aviation Purpose. Frankfurt: Peter Lang. 332 p.

BRUNFAUT, T. 2014. Language for Specific Purposes: Current and Future Issues. Language Assessment Quarterly. 11.2: p.216-225. Informa UK Limited. Available at: $<$ http://dx.doi.org/10.1080/15434303.2014.902060>. Access: 30 Mar. 2020.

CHENG, L. 2005. Changing language teaching through language testing: a washback study. Cambridge: Cambridge, 2005. 342 p.

DOUGLAS, D. 2000. Assessing Languages for Specific Purposes. Cambridge: Cambridge University Press. $311 \mathrm{p}$.

2001. Language for Specific Purposes assessment criteria: where do they come from? Language Testing. 2. 18: p. 171-185. Available at: $<$ http://ti.sagepub.com/content/18/2/171.full.pdf $>$. Access: 19 Jan. 2020.

. D. 2005. Testing Language for Specific Purposes. In: HINKEL, Eli (Ed.). Handbook of Research in Second Language Teaching and Learning: Routledge. p. 857-868. Available at: $<$ https://www.taylorfrancis.com/books/e/9781410612700/chapters/10.4324/9781410612700-63>. Access: 23 Jan. 2020.

. 2010. Understanding Language Testing. U. K.: Hodder Education, 2010. 156 p.

. 2013. ESP and Assessment. In: PALTRIDGE, B.; S. STARFIELD. (Eds.). Handbook of English for Specific Purposes: John Wiley \& Sons, Inc. p. 367-383. Available at :

$<$ https://onlinelibrary.wiley.com/doi/10.1002/9781118339855.ch19>. Access: 23 Jan. 2020.

. 2014. Nobody seems to speak English here today: Enhancing assessment and training in aviation English. Iranian Journal Of Language Teaching Research, 2. 2: p.1-12. Available at: $<$ https://files.eric.ed.gov/fulltext/EJ1127407.pdf $>$. Access: 23 Jan. 2020.

DUDLEY-EVANS, T.; M.J. ST. JOHN. 1998. Developments in English for Specific Purposes: a multidisciplinar approach. Cambridge: Cambridge University Press. 301 p.

ELDER, C. 2015. Exploring the limits of authenticity in LSP testing: The case of a specific-purpose language test for health professionals. Language Testing. 33. 2: p.147-152. Available at: $<$ http://dx.doi.org/10.1177/0265532215607397>. Access: 23 mar. 2020.

EMERY, H. J. 2014. Developments in LSP Testing 30 years on? The Case of Aviation English. Language Assessment Quarterly, vol. 11, n. 2, Reino Unido, p. 198-215. Available at: $<$ http://dx.doi.org/10.1080/15434303.2014.894516>. Access: 22 Mar. 2020.

ESTIVAL, D.; C. FARRIS. 2016. Aviation English as a lingua franca. In: ESTIVAL, D.; C. FARRIS; B. MOLESWORTH (Eds.). Aviation English: A lingua franca for pilots and air traffic controllers. New York: Routledge, p. 1-18, e-book.

FARRIS, C. 2016. Aviation language testing. In: ESTIVAL, D.; C. FARRIS; B. MOLESWORTH (Eds.) Aviation English: A lingua franca for pilots and air traffic controllers. New York: Routledge. p. 75-91, e-book 
FARRIS, C.; B. MOLESWORTH. 2016. Communications between air traffic control and pilots. In: ESTIVAL, D.; C. FARRIS; B. MOLESWORTH (Eds.) Aviation English: A lingua franca for pilots and air traffic controllers. New York: Routledge. p. 92-110, e-book.

FLOWERDEW, L. 2013.Needs Analysis and Curriculum Development in ESP. In: PALTRIDGE, B.; S. STARFIELD (Ed.). The handbook of English for specific purpose. West Sussex: John Wiley \& Sons, p. 325-346. Available at: $<$ https://onlinelibrary.wiley.com/doi/pdf/10.1002/9781118339855.ch17>. Access: 23 Jan. 2020.

GARCIA, A.C.M. 2015. What do ICAO language proficiency test developers and raters have to say about the ICAO language proficiency requirements 12 years after their publication? A qualitative study exploring experienced professionals' opinions. Master's Dissertation, Lancaster University.

HUTCHINSON, T.; A. WATERS. 1987. English for Specific Purposes: A learning-centered approach. Cambridge: Cambridge University Press, 183 p.

INTERNATIONAL CIVIL AVIATION ENGLISH ASSOCIATION/ICAEA. 2019a. ICAO LPR Test Design Guidelines (TDG). Workshop Materials. Session presentations. Available at:

$<$ https://www.icaea.aero/wp-content/uploads/2019/12/ICAEA-TDG-Workshop-Session-2-Revisitingthe-aims-of-the-ICAO-LPRs.pdf>. Access: 23 Mar. 23 Mar. 2020.

INTERNATIONAL CIVIL AVIATION ENGLISH ASSOCIATION/ICAEA. 2019b. ICAO LPR Test

Design Guidelines (TDG). Workshop Handbook Available at: $<$ https://www.icaea.aero/wp-

content/uploads/2019/12/ICAEA-TDG-Workshop-Handbook.pdf>. Access: 23 Mar. 2020.

INTERNACIONAL CIVIL AVIATION ORGANIZATION/ICAO. 2007. Manual of Radiotelephony:

Doc 9432, AN/925. Montreal, Canada. Available at:

$<$ https://www.ealts.com/documents/ICAO $\% 20$ Doc $\% 209432 \% 20$ Manual $\% 20$ of $\% 20$ Radiotelephony $\% 20$ (4th\%20ed.\%202007).pdf $>$. Access: 23 mar. 2020.

INTERNATIONAL CIVIL AVIATION ORGANIZATION/ICAO. 2009a. Language Testing Criteria for Global Harmonization: Circular 318 AN/180. Montreal, Canada. Available at:

$<$ http://aviationenglishclasses.com/icao cir318.pdf>. Access: 23 Mar 2020.

INTERNACIONAL CIVIL AVIATION ORGANIZATION/ICAO. 2009b. Guidelines for Aviation English Training Programs: Circular 323 NA/185, Montreal, Canada. Available at:

$<$ https://www.icao.int/safety/lpr/Documents/323 en.pdf>. Access: 23 Mar 2020.

INTERNATIONAL CIVIL AVIATION ORGAN̄IZATION/ICAO. 2010. Manual on the implementation of ICAO language proficiency requirements: Doc. 9835 AN/453. 2. ed. Montreal, Canada. Available at: $<$ https://skybrary.aero/bookshelf/books/2497.pdf $>$. Access: 23 Mar 2020.

INTERNATIONAL CIVIL AVIATION ORGANIZATION/ICAO. 2016. Air Traffic Manegement. Doc 4444. Montreal, Canada. Available at: $<$ https://ops.group/blog/wp-content/uploads/2017/03/ICAODoc4444-Pans-Atm-16thEdition-2016-OPSGROUP.pdf>. Access: 23 Mar 2020.

ISHIHARA, N.; M.C.A. PRADO. Forthcoming. The negotiation of meaning in aviation English as a lingua franca: a corpus-informed discursive approach.

JENKINS, J. 2000. The phonology of English as an International Language. Oxford: Oxford University Press.

. 2018. The future of English as a Lingua Franca? In: JENKINS, J.; W. BAKER, \& M.

DEWEY (Eds.) The Routledge Handbook of English as a Lingua Franca. New York: Routledge, p. 594605.

KATSARSKA, V. 2017. Harmonization of University Aviation Courses. The Journal Of Teaching English For Specific And Academic Purposes, 5.3: 449-458. Available at:

$<$ http://espeap.junis.ni.ac.rs/index.php/espeap/article/view/538>. Access: 23 Jan. 2020.

KIM, H.; C. ELDER, C. 2009. Understanding aviation English as lingua franca. Australian Review of Applied Linguistics: Understanding English as a lingua Franca articles. 32.3: 23.1-23.17. Available at: $<$ https://benjamins.com/catalog/aral.32.3.03kim>. Access: 26 Mar. 2020. 
KIM, H. 2013. Exploring the construct of radiotelephony communication: a critique of the ICAO English testing policy from the perspective of Korean experts. Papers In Language Testing And Assessment. 2.2: 103-110. Available at:

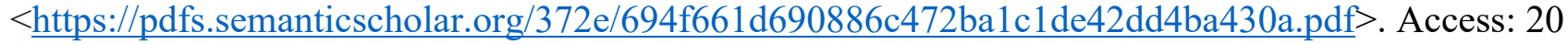
Mar. 2020.

2018. What constitutes professional communication in aviation: Is language proficiency enough for testing purposes?. Language Testing, 35.3: 403-426. SAGE Publications.

http://dx.doi.org/10.1177/0265532218758127. Available at:

$<$ https://www.researchgate.net/publication/325856717 What constitutes_professional communication in aviation_Is language proficiency enough for testing purposes $>$. Access: 23 Jan. 2020.

KNOCH, U. 2014. Using subject specialists to validate an ESP rating scale: The case of the International Civil Aviation Organization (ICAO) rating scale. English for Specific Purposes. 33, 77: 86. Available at:

$<$ https://www.sciencedirect.com/search?qs $=$ Using $\% 20$ subject $\% 20$ specialists $\% 20$ to $\% 20$ validate $\% 20$ an $\%$ 20ESP $\% 20$ rating $\% 20$ scale $\% 3 \mathrm{~A} \% 20$ The $\% 20$ case $\% 20$ of $\% 20$ the $\% 20$ International $\% 20$ Civil $\% 20$ Aviation \%20Organization $\% 20 \% 28 \mathrm{ICAO} \% 29 \% 20$ rating\%20scale>. Access: 22 Apr. 2020

KNOCH, U.; S. MACQUEEN. 2020. Assessing English for Professional Purposes. New York:

Routledge, 2020. $211 \mathrm{p}$.

LOPEZ, S.; A. CONDAMINES; A. JOSSELIN-LERAY. 2011. An LSP Learner Corpus to help with English Radiotelephony Teaching. In: Granger, S.; G. Gilquin; F. Meunier (Eds.) Twenty Years of Learner Corpus Research: Looking back, Moving ahead. Proceedings of Learner Corpus Research, Louvain-la-Neuve: Prenses universitaires de Louvain, 301-311.

LLOSA, L. Forthcoming. Revisiting the role of content in language assessment constructs. In: OCKEY, G.; B. GREEN (Eds.). A next generation of fundamental considerations in language assessment: A festshrift in honor of Lyle F. Bachman. New York: Springer.

MATHEWS, E. 2004. Aviation Language. Presentation delivered at the ICAO Aviation Language Symposium of 2004 in Montreal. August 2004.

. 2020. Opinion: How Incomplete Language Standards Threaten Aviation. March 03, 2020. In: Aviation Week. Available at: $<$ https://aviationweek.com/air-transport/opinion-howincomplete-language-standards-threaten-aviation? fbclid=IwAR262pq8-

6McH6YkH7_1PvpsXOAHI0cogGfANrsd7TbU0N4pufWxqeDPSZI>. Access: 30 Mar. 2020. MODER, C. L. 2013. Aviation English. In: PALTRIDGE, B.; S. STARFIELD (Eds.). Handbook of English for Specific Purposes: John Wiley \& Sons, Inc. Cap. 12. p. 227-242. Available at :

$<$ https://onlinelibrary.wiley.com/doi/abs/10.1002/9781405198431.wbeal0068>. Access: 23 Jan. 2020.

MODER, C. L.; G.B. HALLECK, 2009. Planes, politics and oral proficiency. Australian Review of Applied Linguistics, 32.3: 25.1-25.16, 1 jan. 2009. John Benjamins Publishing Company. Available at: $<$ https://eric.ed.gov/?id=EJ867281>. Access: 23 Jan. 2020.

MONTEIRO, A.L. 2019. From a Language-Only Approach to a Broader View of Communicative Competence for Intercultural Communications in Aviation. International Civil Aviation English Association. 3. Available at: <https://commons.erau.edu/icaea-workshop/2019/day-3/3>. Access: 30 Mar. 2020.

PRADO, M.C.A. 2019. A relevância da pragmática no ensino do inglês aeronáutico: Um estudo baseado em corpora. Doctoral dissertation, Universidade de São Paulo. Avaliable at: <www.teses.usp.br>. Access: 30 Mar. 2020.

PRADO, M.C.A.; P. TOSQUI-LUCKS. 2017. Are the LPRs focusing on real life communications issues? Internation Civil Aviation English Association. Dubrovnik: Embry-Riddle Scholarly Commons, p. 1-20. 
. 2019. Designing the Radiotelephony Plain English Corpus

(RTPEC): A specialized spoken English language corpus towards a description of aeronautical communications in non-routine situations. Research in Corpus Linguistics, 7: 113-128.

ROBERTS, J.; A. ORR. 2020. Language Education for Ab Initio Flight Training: a plan going forward. In: KEARNS, S. K.; T. J. MAVIN; S. HODGE (Eds.). Engaging the next generation of aviation professionals. N.Y: Routledge, 2020. p. 149-162

ROBINSON, P. 1991. ESP Today: a Practitioner's Guide. Hemel Hempstead: Prentice Hall International. $146 \mathrm{p}$.

SCARAMUCCI, M. V. R. 2011. O Exame de proficiência em língua inglesa para controladores de voo do SISICEAB: uma entrevista com Matilde Scaramucci. Aviation in focus, Porto Alegre. 2.1: 3-12, jan./jul. Available at: $<$ https://geia.icea.gov.br/geia/publicacoes.php $>$. Access: 23 Jan 2020.

SCARAMUCCI, M. V. R.; P. TOSQUI-LUCKS; S. M. DAMIÃO (Eds). 2018 Pesquisas sobre inglês aeronáutico no Brasil. Campinas: Pontes Editores.

SILVA, A. L. B. C. 2016a. Uma análise de necessidades de uso da língua inglesa por oficiais aviadores do esquadrão de demonstração aérea da força aérea brasileira. Master's Dissertation Instituto de Estudos da Linguagem, UniversidadeEstadual de Campinas, Campinas. Available at:

$<$ http://repositorio.unicamp.br/stats?level=item\&type $=$ access \&page $=$ downviewsseries\&object=item\&object-id=REPOSIP/320921>. Access: 23 Mar. 2020.

2016b. A Análise de Necessidades e sua relação com cursos e avaliação de proficiência em inglês para um grupo de pilotos militares brasileiros. Estudos Linguísticos. 45.2: 490503. Available at: $<$ https://revistas.gel.org.br/estudos-linguisticos/article/view/585>. Access: $23 \mathrm{Mar}$. 2020.

.2018. Análise de necessidades para a definição da proficiência em inglês dos pilotos da Esquadrilha da Fumaça. In: SCARAMUCCI, M. V. R.; P. TOSQUI-LUCKS; S. M. DAMIÃO (Eds.) Pesquisas sobre inglês aeronáutico no Brasil. Campinas: Pontes, p. 115-132.

. 2019. O inglês necessário aos pilotos da "Esquadrilha da Fumaça": quão específica pode ser a língua paa fins específicos? Revista Estudos Linguísticos, 48.1: 118-139. Available at: $<$ https://revistas.gel.org.br/estudos-linguisticos/article/view/2131>. Access: 23 Mar. 2020.

SOLOVOVA, O.; J.V. SANTOS; J. VERISSIMO. 2018. Publish in English or Perish in Portuguese: Struggles and Constraints on the Semiperiphery. MDPI Publications, 6: 25. Available at:

$<$ https://www.researchgate.net/publication/325560032_Publish_in_English_or_Perish_in_Portuguese_S truggles and Constraints on the Semiperiphery>. Access: 02 May 2020.

TOSQUI-LUCKS, P. 2018. Aplicações de corpora no ensino e na avaliação de inglês aeronáutico: estado da arte, reflexões, direcionamentos. In: SCARAMUCCI, M. V. R.; P. TOSQUI-LUCKS; S. M. DAMIÃO. Pesquisas sobre Inglês Aeronáutico no Brasil. Campinas: Pontes, p. 89-114. TOSQUI-LUCKS, P.; A.L.B.C., SILVA. 2020. Da elaboração de um glossário colaborativo à discussão sobre os termos "inglês para aviação" e "inglês aeronáutico". Estudos Linguísticos, São Paulo, 49.1: $97-$ 116. Disponível em: $<$ https://revistas.gel.org.br/estudos-linguisticos/article/view/2561>. Acesso em: 02 maio 2020.

WIDDOWSON, H. 1994. The ownership of English. TESOL Quarterly, 28.2: 377-389. 
Patrícia Tosqui-Lucks holds a PhD in Linguistics from Sao Paulo State University (Unesp), focused on English for Specific Purposes, and recently finished a post-doctoral research on Corpus Linguistics at the University of Sao Paulo (USP), in Brazil. With over 20 years of experience teaching English in various contexts, she has been the supervisor of the Aeronautical English Training Programme for air traffic controllers at the Brazilian Airspace Control Institute (ICEA) since 2009. She is also the leader of GEIA, an aeronautical English research group that brings together practitioners in the fields of teaching, assessment, language description, and teacher training. The objective of her current research is to inform the development of aeronautical English curricula and assessment using Corpus Linguistics tools.

Ana Lígia Barbosa de Carvalho e Silva is a PhD student in the Applied Linguistics program at the University of Campinas (Unicamp), Brazil, with a scholarship from CAPES. She holds a post-graduate degree in EFL teaching and a Cambridge CELTA certificate. She has taught English for occupational purposes for more than twenty years and is a member of GEIA. Her research interests include language assessment in ESP, with special focus on language needs analysis, test design and language proficiency for military pilots. Lately, Ligia has presented studies in different international events, such as AILA, LTRC, ECOLT and British Council New Directions. 